\title{
AZ EGYETEMI KÁBÍTÓSZER-DISZTRIBÚCIÓ
}

\section{THE UNIVERSITY DRUG DISTRIBUTION}

\author{
Dési Ádám \\ PhD-hallgató, Eötvös Lóránd Tudományegyetem Állam- és Jogtudományi Kar Kriminológiai Tanszék \\ desiadam.d@gmail.com
}

\begin{abstract}
ÖSSZEFOGLALÁS
A tanulmány célja az egyetemi karrierrel párhuzamosan kialakuló kábítószer-terjesztés okainak és jellemzőinek bemutatása. A kialakuló terjesztési karrier megértéséhez szükséges a rendszerbe való belépéstől való védettségi tényezők feltárása is, illusztrálva hogyan bír egyszerre visszatartó és tolóerővel a kockázatok eltérő értékelése. Ezen keresztül bemutatom, hogy melyek a jellemző állomásai a terjesztői karriernek, ezeket pedig miként befolyásolják a résztvevők és környezetük társadalmi helyzete.
\end{abstract}

\section{ABSTRACT}

This paper focuses on the question, that why are some university students starting drug dealing carriers, and what are the main features of this scene. Understanding the drug dealing carrier in its development the protecting factors have to be explored, how it is possible that the different risk assessments have an including and an excluding effect at the same time. Through this example I present the main stages of the university drug dealing careers, and how the participants and their social status influence that.

Kulcsszavak: kábítószer, kábítószer-kereskedelem, egyetem, közösségi ellátás, normalizáció, társadalmi státusz

Keywords: drugs, drug distribution, university, social supply, normalization, social status

\section{BEVEZETÉS}

Magyarországon az egyetemi hallgatói közösség egy jelentősebb része végez valamiféle diákmunkát, akár kifejezetten a megélhetéséért, vagy csak kiegészítő jövedelem megszerzése céljából. Elöfordul, hogy néhányan közülük az illegális kábítószer-kereskedelem felé fordulnak, árukészletük pedig a marihuánától kezdve az amfetaminszármazékokon keresztül akár az LSD-ig is terjedhet. Ahogy csoporttársaik befejezik felsőoktatási tanulmányaikat és ezzel együtt a 
legális diákmunkát is, a legtöbb esetben ugyanez a karrierút játszódik le a kábítószer-disztribúcióban is, az egyetemi tanulmányok után csupán a terjesztők töredéke maradt aktív résztvevője a kábítószer-kereskedelemnek (MohamedFritsvold, 2010).

A felsőoktatási hallgatók mint speciális fogyasztói csoport vizsgálata mind a hazai, mind a külföldi szakirodalomban része a kábítószer-kutatásoknak, új és fontos résztéma például a vényköteles gyógyszerek tanulássegítő alkalmazása vagy éppen a szórakozóhelyeken történő és a speciális zenei szubkultúrákkal összefonódó fogyasztás (Demetrovics-Rácz, 2008; Rácz, 2006). Azonban a disztribúció jelensége a terjesztői oldalról, főleg kvalitatív szempontból kevéssé kutatottnak nevezhető. Ennek oka, egyfelöl, hogy a tudományos közélet eddig elsősorban a marginalizált helyzetü csoportokra fókuszált, ezzel indirekt módon a kriminológia és a kriminológusok maguk is fenntartóik és megerősítőik annak a narratívának, mely szerint a kábítószer-probléma szinte kizárólagosan, homogén egységként a hátrányos helyzetủ csoportokkal kapcsolódik össze, valamint akár a függőséggel is. Az egyetemi kábítószerhelyzet iránti alacsonyabb szakmai érdeklődésnek az is lehetséges magyarázata, hogy az egyetemi színtér egyik általános, sztereotipikus jellemzője a kábítószer-fogyasztás. Ez a fajta elvárás az ifjúsági szubkultúra mítoszának szükségszerü, szinte elvárt kellékévé vált, ami magától értetődősége miatt így kevesebb szakmai figyelmet kapott, szemben a marginalizált közösségek és a kábítószerek kapcsolatának vizsgálatával.

Az egyetemi színtér sajátossága az epizodikus kriminális karriert folyamatában egyszerre jellemző baráti szívesség, a reciprocitás és a szigorúan profitorientált üzleti szemlélet.

A kizárólagos saját fogyasztás és a profitorientált terjesztés véglete között, a vizsgált csoportra markánsan jellemző, köztes/átmeneti állapotot az angolszász szakirodalom a közösségi ellátás (social supply) fogalmával írja le, melynek központi eleme a disztribúció (szub)kultúrán belüli normalizálódása. Emellett kiemelt jelentőségü, hogy a közösségi ellátásban részt vevők az esetek többségében zárt elosztói hálózatot müködtetnek, amit egyaránt jellemez az erőszak teljes hiánya, illetve az elhanyagolható vagy egyenesen semmilyen közvetlen gazdasági profit.

\section{MÓDSZERTAN}

A dolgozat empirikus alapját a hólabda és a networking (Rácz, 2006) toborzási módszeren alapuló kvalitatív pilotkutatás jelenti. Az adatfelvétel keretein belül összesen tizenkét személlyel, átlagosan másfél óra hosszan, vegyesen fogyasztókkal, közösségi ellátókkal és a profitorientált terjesztésben érdekelt budapesti 
hallgatókkal készítettem félig strukturált interjúkat. Szerepmegoszlás tekintetében harmaduk volt érdekelt a terjesztésben, egyikük user-dealerként (fogyasztó-terjesztő) saját függőségbe forduló fogyasztása miatt, ketten az alacsony szintü kereskedelemben vettek részt, egyikük pedig elsődleges megélhetési forrásként vett részt a kábítószer-kereskedelemben.

Az interjúk elsődleges célja az egyetemi kábítószer-szcéna, annak egyedi, zárt piaci jellemzői és a müködés megismerése volt. Megkülönböztetve azt az (angolszász) szakirodalom túlsúlyából következő nyílt piaci megközelítéstől, valamint a marginalizált szereplők vizsgálatától.

Az interjúkat kiegészítette egy kisebb, hat főből álló fogyasztói körrel lefolytatott fókuszcsoportos beszélgetés, a csoport egyszerre jelentett baráti társaságot és adott fogyasztási egységet. A beszélgetés elsődleges célja a baráti társaság és a fogyasztási stratégiák megismerése volt, ezen keresztül pedig megfigyelni, hogy a kábítószer ellátás csatornái miként állandósulnak, és válnak stabil szereppé vagy akár az identitás részévé.

A szövegben felhasznált interjúrészleteknél külön jelöltem azt, hogy melyik csoportba tartozik az adott személy, vagyis fogyasztó, közösségi ellátó vagy profitorientált terjesztő az illető.

\section{AZ EGYETEMI KÁBITTÓSZERPIAC ÁLTALÁNOS HELYZETE}

A kábítószer egyértelmủen üzleti vállalkozás, az illegális piacok közül az egyik legnagyobb, kiterjedtségében és jövedelmezőségében egyaránt (Ritter, 2005). A kereslet-kínálat törvényének engedelmeskedve alkalmazkodik az egyes fogyasztási csoportok társadalmi és kulturális jellemzőihez, vagyis a kábítószerpiac rendkívül fragmentált, nem képzelhető el homogén egységként. Az egyik színtéren jól bevált taktika a másikon alkalmazhatatlannak bizonyulhat, mint például a territorialitáson alapuló piac és az arra épülö szigorúan hierarchikus szervezetek müködése (Decker-Pyrooz, 2014).

Az egyetemi környezet saját kulturális kódjaival és speciális jól meghatározott fogyasztói körével alapjaiban határozza meg a színtér müködését. A résztvevők szocioökonómiai helyzete alapvető láthatatlanságot és ezzel védettséget biztosít az igazságszolgáltatással szemben, az egyetemen tevékenykedő terjesztők egyértelműen nem célpontok a kábítószer elleni háborúban (Mohamed-Fritsvold, 2010), hiszen ők jellemzően olyan fiatal felnőttek, akik gazdasági és kulturális tőke szempontjából inkább tekinthetők stabil középosztálybelieknek.

A kábítószer-fogyasztással szemben az egyetemi környezetben a kortárs csoport jóval elfogadóbb, mint a széles társadalmi közeg, inkább jellemző az elfogadása, és nem tekintik devianciának (Münnich, 2003; Rácz, 2006). Ezt 
a jelenséget a normalizáció helyi területének fogalmával írhatjuk le. Az elmélet a normalizációs megközelítés aktualizált változata, mely alapjaiban azt írja körül, hogy (bizonyos) kábítószer-fogyasztási szokások a deviáns marginalizált pozícióból az elfogadott(abb) felé mozdultak el, „a kilencvenes évekre önálló fogyasztóvá vált, kockázatkereső fiatalok szabadidős tevékenységének, fogyasztási szokásainak elfogadott, normális részévé vált, normalizálódott a pszichoaktív szerek használata" (Elekes, 2009, 28.). A normalizáció helyi területe annyiban pontosít az eredeti elképzelésen, hogy a kábítószerek megítélése továbbra se jelent sem egységes és általános társadalmi elfogadottságot, sem pedig általános napi szintủ szerhasználatot, csupán relatív elfogadottságot jól körülhatárolható kisebb körökben. Az elfogadottság a fogyasztáson túl kiterjed a közösségi ellátás jellegủ disztribúcióra is, melyet a résztvevők igyekeznek élesen elkülöníteni az üzleti jellegütől (Coomber et al., 2016). A jelenségre már korábbi hazai kutatások is felhívták a figyelmet a budapesti egyetemi marihuána-fogyasztók vizsgálatánál, ,a marihuána-használat elterjedtségénél jobban tolerált a budapesti egyetemisták között: azaz, azok is tolerálják, akik nem használják. Használata részévé vált az egyetemista életnek" (Rácz, 2006, 119.). Ezzel egyértelmüen megalapozva a helyi szintủ normalizáció elméletét a hazai szakirodalomban.

\section{A VÉDETTSÉG KRIMINOLÓGIAI ELMÉLETE}

Ahhoz, hogy megértsük, miért fordulnak egyetemi hallgatók a kábítószerek terjesztése felé, érdemes feltárni azokat a különböző védelmező tényezőket, melyek távol tartják őket a disztribúciós tevékenységtől. A kriminológiai diszciplínán belül ezt a megközelítést az úgynevezett kontrollelméletek képviselik, ahol a bünözés okainak feltárása helyett a vizsgálatok fókuszában a normák betartásának okai szerepelnek, ,léteznek olyan kontrollmechanizmusok, amelyek visszatartanak minket az amúgy természetes és racionális normaszegéstől” (Győry, 2016, 177.).

A kábítószer-terjesztéssel foglalkozó szakirodalom abban megegyezik, hogy a kereskedelmi tevékenység szinte minden esetben együtt jár valamilyen mértékü elözetes fogyasztással is (Murphy et al., 1990). Bizonyos esetekben kifejezetten a függőség, az exponenciálisan növekvő kábítószer iránti igény az elsődleges oka a terjesztési karrier kialakulásának, ezeket a szereplőket (user-dealer) néven kategorizálja a szakirodalom. A terjesztők ezen csoportja számára az árusítás lényegében az egyetlen eszköz, mellyel fedezni tudják kábítószer szükségletüket (Moyle, 2013). 


\section{A VÉDETTSÉG EMPIRIKUS MEGJELENÉSE}

A terjesztés lehetősége és gondolata a legtöbb fogyasztónál felmerül egy adott ponton, hiszen ismerik a helyszínt, megvannak a kapcsolataik a beszerzéshez és az árusításhoz egyaránt, és értenek magukhoz a szerekhez is. Ismerik a kör tolvajnyelvét, legfontosabb jellemzöit, és otthonosan mozognak a területen. Ahogy az egyik fogyasztó megfogalmazta: „Szerintem ez mindenkinek megfordul a fejében, amúgy annak, aki sok füvet szív. Az biztos, hogy mindenki legalább egyszer gondol rá, hogy ezt kéne csinálni, sokan meg is próbálják. Nagyon sok ismerősöm van, aki próbálta már." Azonban az egyetemi színtéren a függőség kialakulásának esélye jelentősen csekélyebb. A szereplők, vagyis az egyetemi hallgatók, nagyobb védettséget élveznek az erősebb szociális hálójuk, a biztos(abb) jövőképük, valamint a magasabb társadalmi státuszuk és az azzal járó kulturális tőkéjük következtében.

A diplomás elhelyezkedés akár itthon, akár külföldön egyaránt hozzáférhető legális karriert és mobilizációt biztosító opció, melyet nem érdemes kockáztatniuk. Ahogy a fókuszcsoport egyik résztvevője megfogalmazta: „,nekem kicsit ilyen Suzuki Swift-szindróma, hogy a nyereségre nincs szükségem, a kockázat az meg nagy. Kurva nagy a kockázat, és semmi értelmes nyereség. Nem egy jó biznisz" (fogyasztó). A fogyasztók jelentős részénél ez tudatos döntés, meghúzzák azt a határt, ahol és amennyire hajlandók kockáztatni, vagyis nem mennek bele profitalapú üzleti terjesztésbe, igyekeznek kicsik maradni. Részben a várható nyereség alacsony szintje miatt, hiszen a családi hátterük következtében (a reprezentativitásra nem törekvő mintába kerültek alapján) nincs égető szükségük a gyors jövedelemszerzésre, a költség-haszon elemzésük másik oldala pedig az időtényező.

„És akkor mindenkinek éjfélkor jut eszébe, hogy kéne mokkot szerezni, tehát ez így, persze az, hogy így dugogatják oda az ezrest, hogy Beszállok! Beszállok! De azt sokszor nem értik az emberek, hogy... túl lazának gondolják" (közösségi ellátó). Azzal, hogy fokozatosan áttérnének a fogyasztásról az azt kiszolgáló szolgáltatásba, a jelenség munkává válna, ami már az élvezet kárára történne. Jelentős mennyiségü időt emészt fel, miközben az alacsony és biztonságos(abb) szinten nem is lehet vele olyan jól keresni. Az eddigi szórakozási forma nehézséget, megoldandó problémákat jelent, amire a legtöbbjüknek egyszerủen nincs szükségük az életében, „,nem tudnám külön választani a barátokat, meg az üzleti dolgot, és simán odaadnám akkor is, ha nincs pénze" (fogyasztó).

\section{A KARRIERÚT: FOGYASZTÁS-KÖZÖSSÉGI ELLÁTÁS-TERJESZTÉS}

A jelenlegi kutatások alátámasztják azt a hipotézist, hogy az egyetemi terjesztés motivációi a privilegizált osztályhelyzet miatt jelentősebb eltérést mutatnak a hagyományosnak nevezhető kábítószer-terjesztéssel szemben, ahol a marginalizált 
helyzetủ résztvevőknél a terjesztésbe való bekapcsolódás gyakran a mobilizáció egyetlen elérhető eszköze (Venkatesh, 2008). Az egyetemi színtér szereplöinél a belépés oka inkább az alábbiak keveréke: a saját fogyasztás támogatása, a pénzügyi függetlenség megteremtése, lázadási motívumok, a devianciaérzet biztonságos megélése, konfrontáció a szülöi függő helyzettel vagy akár a szélesebb társadalmi sztereotípiákkal, valamint a maszkulin identitás önkifejezése (Mohamed- Fritsvold, 2010).

Az illegális szerekhez való korlátozott hozzáférés következtében a fogyasztók a legtöbb esetben nem tudják közvetlenül beszerezni a megvásárolni szándékozott terméket, hanem csak közvetítöi láncolaton keresztül. Az utolsó előtti szereplő az egyetemi fogyasztási színtéren a közösségi ellátó, aki rendelkezik a megfelelő kapcsolatokkal, képes hozzájutni a szükséges kábítószerekhez, azonban ebben a minőségében elsősorban csak az ismerőseinek, közeli barátainak segít, és elhanyagolható profitrátával dolgozik, vagyis nem üzletként, hanem baráti szívességként értelmezi tevékenységét (Dési, 2017).

„És amikor még csak így fogyasztgattunk, akkor így mondták, hogy jó akkor hozzál nekem is egyet stb. Aztán, ugyanakkor meg az, hogy lecsípek a másikéból, ha nem vagyunk annyira jóban, vagy ráteszek egy 500 -ast vagy valami, hogy azért mégiscsak. Hogyha elmegyek én valamiért, akkor legyen már nekem is ebböl kifizetődő" (profitorientált terjesztő).

„... tehát semmiképpen nem akarnám, mondjuk, többért eladni valakinek, mint amennyiért ő meg tudná venni. Vagy maximum csak azért, hogy a végén nullára jöjjek ki. De, mondjuk, én azt nem tartanám nagyon felháborítónak, ha mondjuk, veszek sokat, és emiatt kedvezményesen kapom, akkor azt a rést megtartanám. Annak fényében, hogy mennyi macera, meg mennyi stressz" (közösségi ellátó).

A közösségi ellátói szerep azonban magában hordozza, hogy a szükebb baráti körön túl is elterjed a híre, hogy az adott személynek biztos kapcsolatai vannak, ebböl következik, hogy lehet hozzá kábítószer beszerzéssel kapcsolatban fordulni. Ha a rendelések mennyisége növekszik, azzal egyenes arányban a közösségi ellátót fenyegető kockázatok is nőnek, hiszen egyre gyakrabban kell felkeresnie a terjesztőjét, hogy megfeleljen az ismerősök kéréseinek. Ahogy a közvetlen baráti kapcsolatokat átveszik a közvetettebb gyenge kötések, egyre kevésbé igazolható, hogy csak a szük baráti (fogyasztói) körének segít, amelyben ez elvárt magatartás. A marihuána-fogyasztást magába foglaló (szub) kultúrában a fogyasztás és a szer barátokkal való megosztása egymástól elválaszthatatlan cselekmények. A reciprocitáson alapuló rendszer nem altruista magatartás, hanem alapvető elvárás egymással szemben, biztosítva a fogyasztói kör számára a marihuána folyamatos hozzáférését és jövőbeli megosztását (Belackova-Vaccaro, 2013; Hammersvik, 2018). A saját fogyasztói körön túlra való terjeszkedés viszont fokozatosan mentesíti a közösségi ellátókat ettől az internalizált kontrolltól. 
Ahogy az alábbi idézet is illusztrálja, a növekvő kockázatokra tekintettel csak akkor éri meg fenntartani a disztribúciós magatartást, ha a haszon a költségekkel együtt arányosan nő, „tehát rohadt idegesítő mindennap elfutkározni érte, vagy mindennap háromszor találkozni. Mert »ja, akkor bocs, tudnál nekem is hozni«, és nyilván nem küldhetem oda a gyereket, amikor nem ismeri, vagy esetleg nincs olyan kapcsolatban, hogy tudja a telefonszámát, meg ilyenek" (profitorientált terjesztö).

\section{SIKERES ÜZLETI MODELL?}

Felmerül a kérdés, mennyiben lehet sikeresnek nevezni az egyetemi karrierrel párhuzamosan kialakuló terjesztést. A résztvevők számára a gazdasági tőke felhalmozása nem explicit cél. Ugyanakkor érdekükben áll fenntartani azt az identitásbeli képet maguknak és magukról egyaránt, hogy ők nem valódi terjesztők, ezzel kerülve el a stigmatizációt. Hiszen az, aki csak a barátainak segít, sőt számukra egy igényelt szolgáltatást nyújt, az nem tekinthetö „dílernek”, vagyis bünözőnek. Hiszen számukra a terjesztés csak egy ideiglenes állomás, nem munkaszerüen végzik, nem ebből élnek, és csak csekélyebb mennyiséggel foglalkoznak. Többen felelősségüknek és feladatuknak tartják, hogy rajtuk keresztül juthatnak az ismerőseik biztonságosan a fogyasztani és vásárolni kívánt szerekhez (Jacinto et al., 2008).

A nyelvhasználat az egyes fogyasztói csoportokról alapvető információkat árulhat el, ha megfelelö korpusz összeállítására van lehetőségünk, indikátora lehet például az egyes szerek elterjedtségének is (Tücsök, 2016). A nyelvezet a minőségen túl a mennyiségi nagyságrendeket is jelezheti. A felvett interjúk alapján az egyetemi színtéren belül csak a közvetlen fogyasztási és kiskereskedelmi mennyiségeket fedi le kifejezéskészletük, „elég volt csak egy öcskösnyit [5 gramm] összeszedni, ami mondjuk, adott esetben, mondjuk két embert jelent, velem együtt két embert akár, hogy az öcskösnél akkor 9[000]-ért megkaptad az 5.0-át" (közösségi ellátó). Az egyetemi területen hiányoznak azok a kifejezések, melyek a pár grammos mennyiségnél nagyobb egységeket lefednék, hiszen nem kerülnek kapcsolatba ekkora tételekkel. Ezzel szemben a nagykereskedelmi szinten természetesen megvannak ezek a jelölők: „És én azt hittem egyébként, hogy ő az építőiparban dolgozik, mert állandóan telefonált, és csörgött a telefonja, meg a csempékről magyarázott meg malterről, meg minden ilyesmiről. És kiderült, hogy egyébként ő drogdíler, és csak kilósokkal foglalkozik, tehát csak hát ez nekik ilyen kódnyelv volt" (fogyasztó-terjesztö).

A beépült kifejezések köre is bizonyítja, hogy a színtéren az üzlet megmarad az alacsonyabb kereskedelmi mennyiségeknél, ami magában hordozza, hogy a profitráta sem tud jelentősen megugrani. Konkrét értékekre lebontva a marihuána 
ára körülbelül 2500-3000 forint grammonként, ami a gyakorlatban, amíg 5 grammos mennyiség alatt vásárol valaki, inkább 0,8 grammot jelent kézhez kapva. Az egyik profitorientált terjesztő szerint „Hogyha jó helyen kopogtatok, akkor egy tízes olyan 18-20 ezer forint, viszont annyiból jó, hogy a 0,8 grammot is megveszik akár 2500-ért is, úgyhogy jó. És azon, így akkor egy tízesen 10000 forint van", ami azt jelenti, hogy még akik kifejezetten anyagi nyereségért csinálják egyetemi szinten, ők sem nagyon emelkednek nagyságrendileg a napi tízezer forintos küszöb fölé. Vagyis az összeg, amiért jelentős kockázatot vállalnak, nem sokkal több, mint amennyit egy átlagos diákmunkával szintén megkeresnének egy nap alatt.

Az esetlegesen fenyegető büntetési tétel valóban jelentős, azonban maguk a terjesztők a legkevésbé sem érzik magukat valós veszélyben. Ennek oka a hatóság szelektív figyelme, a hallgatók társadalmi státusza folyamatos védelmet jelent számukra, privilegizált helyzetüket pajzsként tudják használni. Az interjúalanyok döntő többsége legfeljebb tüntetéseken, esetleg közúti igazoltatás során került egyáltalán rendőrrel valaha kapcsolatba. „,[V]agy így éppen mentem, ez mindig itt volt a táskámban a mérlegem meg a kis füvem. Mert most így nézz rám! Nem úgy nézek ki, mint aki... soha az életben nem állítottak meg rendőrök" (profitorientált terjesztő).

\section{KÖVETKEZTETÉSEK}

Az egyetemi kábítószer színteret egyfelől jellemzi a zárt piaci logika, melynek közvetlen következménye, hogy az egyes szerekhez való hozzáférés egy olyan speciális tudást jelent, mely erőforrásként is felhasználható. Ennek a kapcsolati tőkének a felhasználásával épül fel, illetve alakul ki a terjesztői karrierút. A disztribúciót segíti, hogy az egyetemi környezetben nem deviánsként, hanem normaközelien kezelik bizonyos kábítószerek fogyasztását, valamint azon túl alacsony szintü terjesztésével is elfogadóak, megengedőek.

Másfelől a szcénát meghatározza a társadalmi státusz biztosította védelem a kriminális karrier kialakulásával szemben, hogy biztosan számolható jövőképpel rendelkeznek a hallgatók. A lebukás esélye alacsony, mivel osztályhelyzetük védelmet biztosít a formális hatalommal szemben, de legtöbbeknek még így is elfogadhatatlan annak az esélye, hogy egész jövőbeli karrierjüket kockára tegyék.

Az anyagi nyereség mértéke még azoknál az egyetemista terjesztőknél is viszonylag alacsony, akik kifejezetten üzleti szemlélettel müködnek, mivel fenn kell tartaniuk azt a képet, hogy nem valódi terjesztők (dílerek). A felmerülő kockázatok eltérő értékelése az, ami mégis egyeseket a profitorientált szerep felé visz. A szórakozás, rekreációs szerhasználat alapja egy adott ba- 
ráti társaság, ami egyben fogyasztói körként és piaci egységként is funkcionál. A csoportot jellemző erős kötések az alapjai a reciprocitás jellegü kábítószer-eloszlás alapjának. Ennek az erős kapcsolatnak a megszünése, gyenge kapcsolatokkal való felváltása a távolabbi ismerősökkel vagy akár ismeretlenekkel lesz az, ami a szórakozás helyett fokozatosan a terjesztés anyagi jellegét helyezi előtérbe.

\section{IRODALOM}

Belackova, V. - Vaccaro, C. A. (2013): "A Friend With Weed Is a Friend Indeed": Understanding the Relationship Between Friendship Identity and Market Relations Among Marijuana Users. Journal of Drug Issues, 43, 3, 289-313. DOI: 10.1177/0022042613475589, https://bit.ly/2NkByLv

Coomber, R. - Moyle, L. - South, N. (2016): The Normalisation of Drug Supply: The Social Supply of Drugs as the "Other Side" of the History of Normalisation. Drugs: Education, Prevention and Policy, 23, 3, 255-263. DOI: 10.3109/09687637.2015.1110565, https:/www.tandfonline. com/doi/full/10.3109/09687637.2015.1110565

Decker, S. H. - Pyrooz, D. C. (2014): Gangs: Another Form of Organized Crime. In: Paoli, L.: The Oxford Handbook of Organized Crime. London: Oxford University Press, 270-287. https://bit. ly/2QAwpg3

Demetrovics Zs. - Rácz J. (szerk.) (2008): Partik, drogok, ártalomcsökkentés. Kvalitatív kutatások a parti-szcénában. Budapest: L'Harmattan Kiadó, http://demetrovics.hu/dokumentumok/Kutatasok_8_DemetrovicsZs_konyv.pdf

Dési Á. D. (2017). A közösségi ellátás mint illegitim kábítószer-terjesztési típus. Themis, 15, 2 , 24-48. http://epa.oszk.hu/02300/02363/00028/pdf/EPA02363_themis_2017_dec_024-048. pdf

Elekes Zs. (2009): Egészségkárositó magatartások és mérési módszerek. https://www.tankonyvtar.hu/hu/tartalom/tamop425/0010_2A_23_Elekes_Zsuzsanna_Egeszsegkarosito_magatartasok_es_meresi_modszerek/ch09s04.html (Letöltve: 2018. 04. 20.)

Győry Cs. (2016): Kontrollelméletek. In: Borbíró A. - Gönczöl K. - Kerezsi K. et al. (szerk.): Kriminológia. Budapest: Wolters Kluwer

Hammersvik, E. (2018): Making Sense of "Helping Friends": "Flexing" Motivational Accounts of Cannabis Growing. Journal of Contemporary Ethnography, 47, 1, 88-112. DOI: $10.1177 / 0891241616662506$

Jacinto, C. - Duterte, M. - Sales, P. et al. (2008): “I'm Not a Real Dealer": The Identity Process of Ecstasy Sellers. Journal of Drug Issues, 38, 2, 419-444. DOI: 10.1177/002204260803800203, https:/www.researchgate.net/publication/254117701_I'm_Not_a_Real_Dealer_The_Identity_ Process_of_Ecstasy_Sellers

Mohamed, R. - Fritsvold, E. (2010): Dorm Room Dealers: Drugs and the Privileges of Race and Class. London: Lynne Rienner

Moyle, L. (2013): An Exploration of how the Social Supply and User-Dealer Supply of Illicit Drugs Differs to Conventional Notions of Drug Dealing and Consideration of the Consequences of this for Sentencing Policy. Plymouth: Plymouth University, https://bit.ly/2NhMnxF

Münnich Á. (szerk.) (2003): A kábítószer kipróbálásának okairól az egyetemi hallgatók körében végzett vizsgálatok alapján. Budapest: Eötvös Kiadó 
Murphy, S. - Waldorf, D. - Reinarman, C. (1990): Drifting into Dealing: Becoming a Cocaine Seller. Qualitative Sociology, 13, 4, 321-343. DOI: 10.1007/BF00989408, https://www.researchgate.net/publication/226278745_Drifting_into_dealing_Becoming_a_cocaine_seller

Rácz J. (2006): Kvalitatív drogkutatások. Budapest: L'Harmattan Kiadó

Ritter, I. (2005): Bevezetés a kábitószer-gazdaságtanba I. (Kriminológiai Tanulmányok 49) 139158. http://www.okri.hu/images/stories/KT/kt49_2012_sec.pdf

Tücsök D. (2016): Kábítószerek megnevezései egy szociolingvisztikai vizsgálat tükrében. In: Bagyinszki S. - Kocsis R. P. (szerk.): Anyanyelvünk évszazadai 2. Budapest: ELTE Magyar Nyelvtörténeti, Szociolingvisztikai és Dialektológiai Tanszék, 165-172. http://real.mtak. $\mathrm{hu} / 48996 /$

Venkatesh, S. (2008): Gang Leader for a Day: A Rogue Sociologist Takes to the Streets. New York: Penguin 